\title{
Publisher's announcement
}

Macmillan Publishers Ltd is pleased to be able to announce the creation of a new company. Nature Publishing Group brings together Nature, the Nature monthly titles and the journals formerly published by Stockton Press. Stockton Press becomes the Specialist Journals division of Nature Publishing Group. The new company will be a partner of the scientific community and will be an innovative, responsive and visible presence in scientific and medical publishing.

Nature Publishing Group will use its unique strengths, skills and global perspective to meet the demands of a rapidly changing and challenging publishing environment. The Group's publications are known for delivering high-quality, high-impact content, fair pricing, rapid publication, global marketing and a substantial presence on the internet. These elements are the key to excellence in selecting, editing, enhancing and delivering scientific information in the future.

As a company, we have three core values: quality, service and visibility. These values are set to benefit all our customers - authors, readers, librarians, societies, companies and others - thus building strong publishing relationships.

\section{Cell Death and Differentiation}

Cell Death and Differentiation is now part of the Specialist Journals division of Nature Publishing Group. It will be marketed and sold from our offices in New York, Tokyo, London and Basingstoke. Within the electronic environment, Cell Death and Differentiation will benefit from a substantial investment in innovative online publishing systems, offering global access, intelligent searches and other essential functions. Librarians will be able to provide their readers with print and online versions of Cell Death and Differentiation through a variety of services, including: OCLC, Ingenta (linking to the BIDS service), SwetsNet, Ebsco, Dawson's InfoQuest and Adonis.

At a time when the basis of traditional journal publishing is undergoing significant changes, Nature Publishing Group aims to support the scientific and medical community's needs for high-quality publication services which provide rapid and easy access to the best of biomedical and clinical results. 